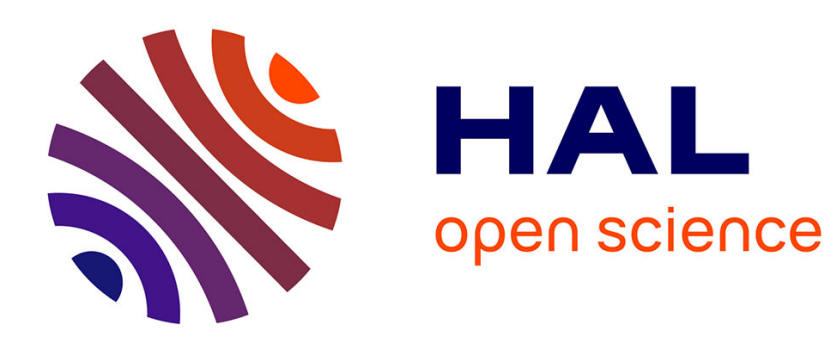

\title{
Sergei Eisenstein and Jean Painlevé: science is animation Marie Rebecchi
}

\section{To cite this version:}

Marie Rebecchi. Sergei Eisenstein and Jean Painlevé: science is animation. Critical Quarterly, 2020, pp.47-59. hal-03226465

\section{HAL Id: hal-03226465 \\ https://hal.science/hal-03226465}

Submitted on 14 May 2021

HAL is a multi-disciplinary open access archive for the deposit and dissemination of scientific research documents, whether they are published or not. The documents may come from teaching and research institutions in France or abroad, or from public or private research centers.
L'archive ouverte pluridisciplinaire HAL, est destinée au dépôt et à la diffusion de documents scientifiques de niveau recherche, publiés ou non, émanant des établissements d'enseignement et de recherche français ou étrangers, des laboratoires publics ou privés. 


\section{Sergei Eisenstein and Jean Painlevé: science is animation ${ }^{1}$}

\section{Paris 1929-1930: the anthropological gaze}

This essay focuses on the correspondence between Sergei Eisenstein and Jean Painlevé, kept at the Archives Jean Painlevé in Paris. The meeting between the two directors dates back to Eisenstein's stay in Paris from November 1929 to May 1930, which preceded his Mexican journey (from December 1930 to February 1932).

Eisenstein's Parisian time is crucial in helping us to understand certain fundamental aspects of his surrealist vision of Mexico, as well as to grasp the influence of his conceptualisation of the principle of 'intellectual and conflicting' montage within 'heterodox' surrealism. The dissident branch of surrealism was predominately represented by Georges Bataille and his journal Documents. ${ }^{2}$ In response to André Breton's Second Surrealist Manifesto, published in December of 1929, ${ }^{3}$ which directly criticised certain members of the movement, the 'expelled' surrealists (Jacques Baron, Jacques-André Boiffard, Georges Ribemont-Dessaignes, Robert Desnos, Georges Limbour, Michel Leiris, Jacques Prévert, Roger Vitrac, etc.) published on 15 January 1930 a pamphlet entitled A Corpse (Un cadavre). In his Memoirs, Eisenstein claims his proximity to the left democratic wing of Surrealists, which had broken away from the Breton faction. They were my friends. ${ }^{4}$

This leads us to identify a common method between Eisenstein and the dissident branch of surrealism, first and foremost through a convergent approach, i.e., said 'conflicting and dialectic montage'. ${ }^{5}$ The convergent method was most effectively explained, on the one hand, through the concept of montage developed by Eisenstein in four essays written during the course of 1929 ('Beyond the Shot', 'Perspectives', 'The Dramaturgy of Film Form' 
['The Dialectical Approach to Film Form'] and 'The Fourth Dimension in Cinema' ${ }^{6}$, and on the other hand, in the dialectical montage of texts and images published in the journal Documents between 1929 and $1930 .^{7}$

The reasons for this convergent approach are to be found in certain events in Eisenstein's life, interwoven with his publishing endeavours for the magazine Documents, in particular the publication of thirty frames from The General Line in a two-page spread in issue 4 in $1930 .{ }^{8}$ Along with an introduction to the film by Robert Desnos, the stills are prefaced by Georges-Henri Rivière thanking Eisenstein for having 'agreed to cut his film, thus providing readers with a completely new illustration, chosen and layout by the author himself. ${ }^{9}$

Later, Eisenstein gave a lecture on intellectual cinema at the Sorbonne on 17 February 1930, which should have coincided with the screening of the film The General Line, organised by the vicepresident of the French Psychoanalytic Society, René Allendy, but the film was banned by the prefect of Paris, Jean Chiappe; the text of the lecture was published immediately by La Revue $d u$ cinéma under the title 'The Principles of New Russian cinema'. ${ }^{10}$ This lecture was attended by many intellectuals of the time, and two thousand people gathered to see the film, ${ }^{11}$ probably including Georges Bataille, Jean Painlevé and others who collaborated with Documents.

Another crucial meeting point between Eisenstein and Documents can be found in the ethnographic direction common to both Eisenstein's line of thinking in the 1930s and to articles published in Documents by Marcel Griaule, Michel Leiris, Paul Rivet, Georges-Henri Rivière, etc. in 1930. The fact that Eisenstein was already reading about ethnography while in Paris - as well as throughout his trip to the Americas, and especially while shooting Que viva Mexico! - confirms this convergence with the group of ethnologists close to Documents. Indeed, it was in Mexico that Eisenstein encountered a clear display of the primitive, pre-logical, and sensory modes of thinking that had been analysed in LévyBruhl's 1922 Primitive Mentality, ${ }^{12}$ which - as he relates in a chapter of his Memoirs called 'Epopée' - he had managed to get hold of during his months-long stay in Paris. Eisenstein wrote that he had kept the book in the wardrobe of his Paris hotel together with works of Christian mysticism by the likes of Saint John of the Cross (San Juan de la Cruz), Saint Teresa and Ignacio de Loyola (Manresa: The Spiritual Exercises), books which formed part 
of the bibliography that guided his 'ecstatic and primitive' vision of Mexico. $^{13}$

It was during this time in Paris (late winter and spring of 1930) that Eisenstein first discovered the 'ethnographic' trend in surrealism, particularly through the mediation of Georges-Henri Rivière, curator of the pre-Columbian art exhibition in whose catalogue Bataille's essay Extinct America ${ }^{14}$ was republished; as he notes in his diary, Eisenstein met Georges Bataille precisely in January 1930 'chez Georges-Henri Rivière'. ${ }^{15}$ In fact Rivière was with Eisenstein when the Russian visited the Trocadero Museum, where he was fascinated by 'artefacts from the Congo and Australia'. ${ }^{16}$

During his Mexican stay, Eisenstein enjoyed a wonderful sense of freedom and disconnection from the ideological rules imposed not only by Soviet authorities, but also by American sponsors of the film with their bottom-line considerations. Mexico became for Eisenstein a blank slate where he could put into practice, directly in the field, the new intellectual notions picked up during his Paris stay, whether from the books about ethnography he continued to read throughout his time in America (in addition to the Lévy-Bruhl work bought in Paris, Eisenstein reveals in the 'Bookshops' chapter of his Memoirs that he brought to Mexico the volumes of Frazer's The Golden Bough, ${ }^{17}$ purchased in the United States), or through his contacts with the 'ethnographic' branch of surrealism. ${ }^{18}$

The crucial aspect of Eisenstein's interest in ethnological studies focusing on the structures of thought and the psyche in primitive societies was his personal and intimate experience which, owing to the atmosphere he found in Mexico, led him to a regressive period of primitive and 'sensory' consciousness (as Lévy-Bruhl writes in Primitive Mentality, this is the non-analytical stage of the thought process, in which causal connections are eschewed). This experience brought him to perceive a link between this regressive moment in his biographic experience and his own theoretical interest in the pre-natal stage of the human experience. ${ }^{19}$

\section{Eisenstein and Painlevé: the correspondence}

In the early 1930s, Eisenstein's intellectual and personal vicissitudes intertwined first with those of the photographer and filmmaker Jean Painlevé (known for his documentary work on the underwater fauna), and later with those of Georges Bataille and the group of intellectuals and anthropologists who animated the journal Documents. Shortly after their meeting, Eisenstein and 
Painlevé developed a strong friendship, as evidenced by correspondence that they maintained during all of Eisenstein's travels in the United States and Mexico (1930-32), up until his return to the Soviet Union.

While Eisenstein was in Paris, Painlevé asked his father (Paul Painlevé, the mathematician and minister of war and aviation from 1917 to 1932) for help in dealing with officials regarding the Sorbonne scandal ${ }^{20}$ and the police notification of his extradition from France, ${ }^{21}$ and Paul Painlevé ordered the head of the French police to leave Eisenstein alone. In one of his letters to Painlevé, Eisenstein entreated Painlevé's father's intervention, ending with the words: 'En vous considerant comme le seul concurrent à N.D. de Lourdes en matière de miracle' (Considering yourself the only competitor to Our Lady of Lourdes in the matter of Miracle). ${ }^{22}$

Painlevé also took Eisenstein on a grand tour of Paris, to the Palais Royal square and to the Comédie-Française. Of this tour, Painlevé would later recall: 'I also took him to the Cigale theatre to see an exceptional American film Red Christmas. Afterward, we wandered around the Clichy fairgrounds ... and had our photo taken in a mock airplane. ${ }^{, 23}$

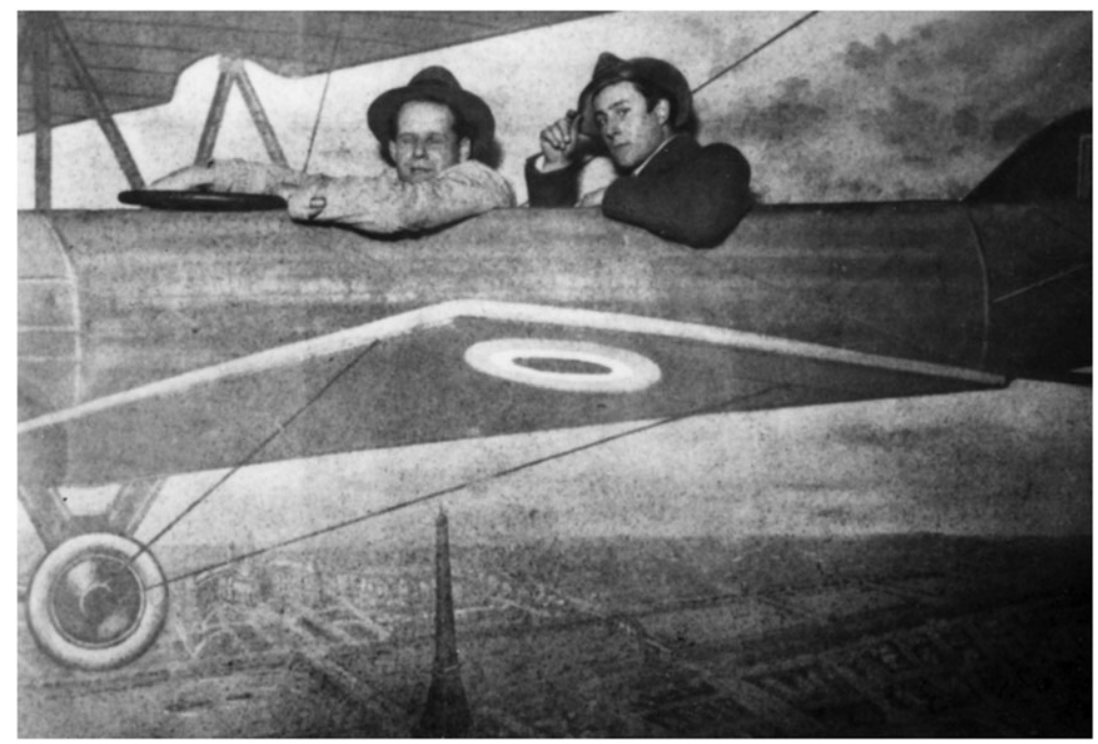

Sergei Eisenstein and Jean Painlevé in Paris, 1930.

(C) Archives Jean Painlevé, Paris 
After leaving Europe, Eisenstein wrote a series of postcards to Painlevé in which he chronicled his travels throughout the United States and then Mexico. Some of the postcards, like the one from New York (12 May 1930), perhaps refer to his quickly dashed hopes of finding freedom in the US.

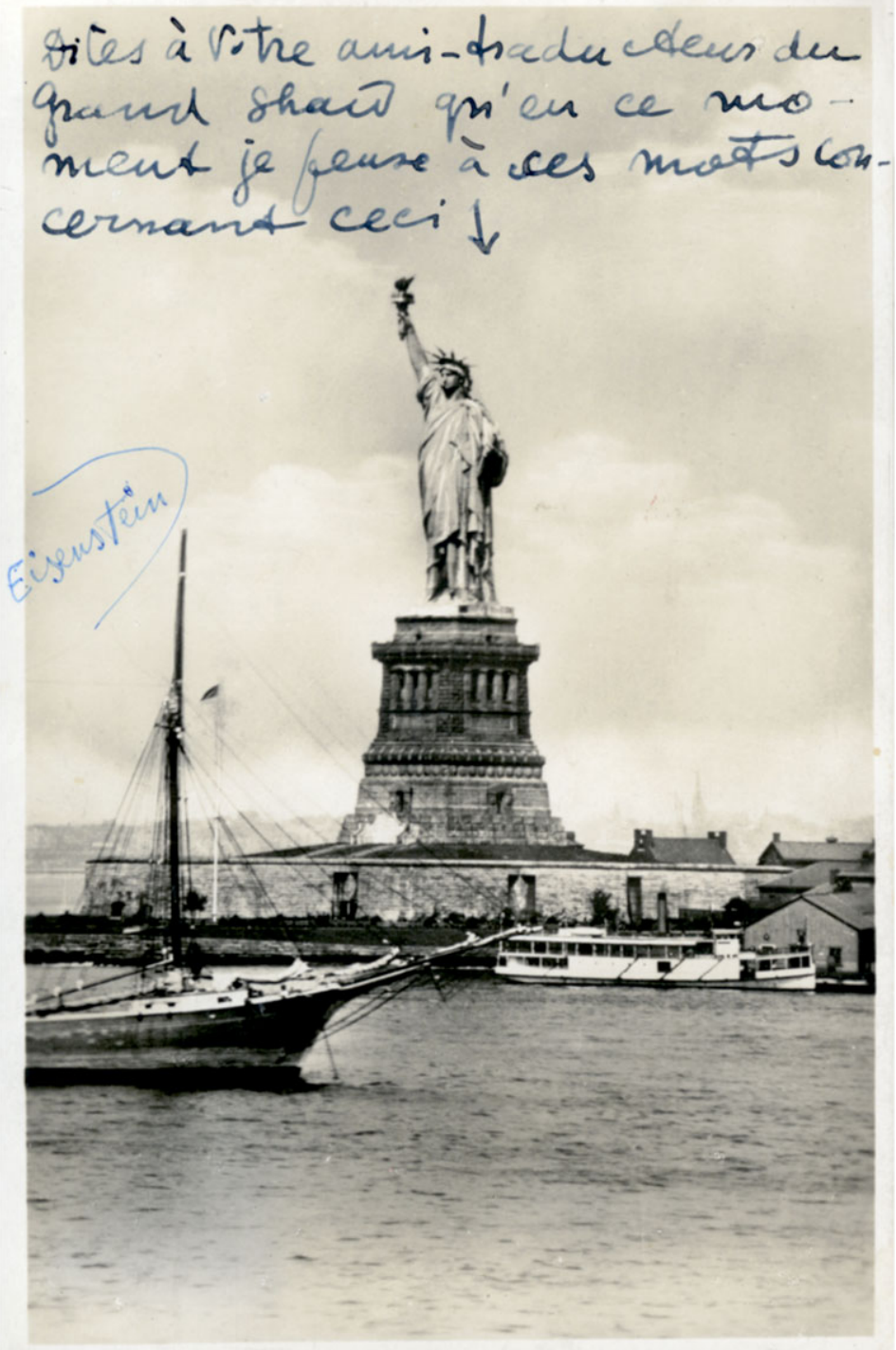

Postcard from Sergei Eisenstein to Jean Painlevé, New York, 12 May 1930. 'Tell your translator-friend of the great Shaw that at this moment I am thinking about his words concerning this.' @) Archives Jean Painlevé, Paris 
In another, from Catalina Island, Eisenstein perhaps makes an allusion to Painlevé's underwater fauna; with the usual humour that imbued all of their correspondence, he wrote: 'Voici encore un tas de sales bêtes pour en faire des films' (Here again are some foul creatures to make films of).

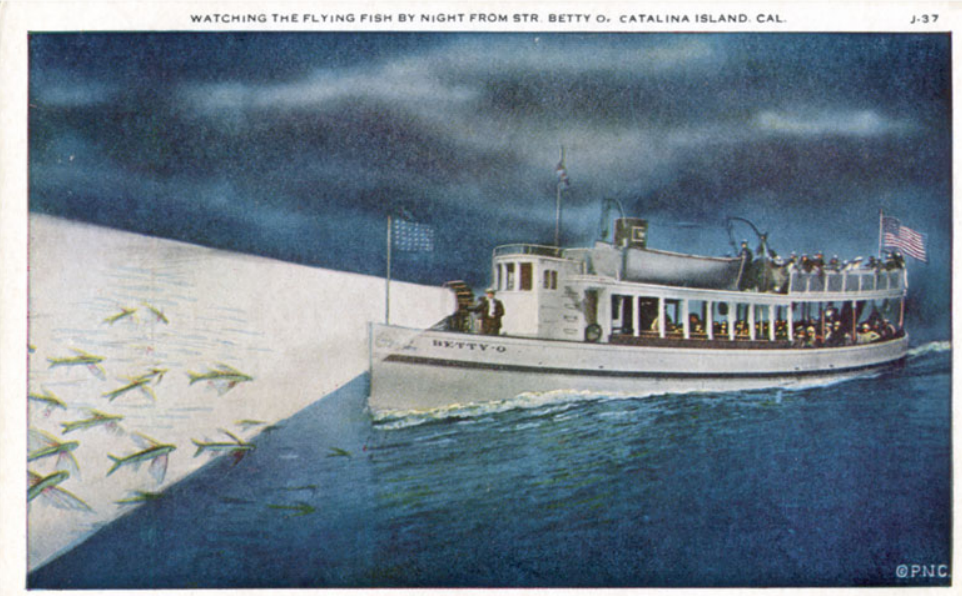

Postcard from Sergei Eisenstein to Jean Painlevé, Catalina Island, undated. (C) Archives Jean Painlevé, Paris

Other postcards, like the one sent from Death Valley, express his impression of Hollywood, of which he sarcastically commented: 'Voici à peu près l'état moral auquel on se réduit à Hollywood' (This is more or less the moral state to which one is reduced to in Hollywood! Between us - so as not to upset the USA).

The correspondence between the two allows us to grasp, on the one hand, the influence of Painlevé's films on Eisenstein's anthropological thinking in the 1930s, and, on the other hand, to reconsider Eisenstein's trip to Paris and his exchanges with prominent figures in 'heterodox' surrealism who were close to Bataille (Painlevé himself included) as a decisive moment in the Soviet director's intellectual and biographical life. One could, in fact, advance the hypothesis that some of Painlevés scientific films - like the one entitled Protoplasm Movement in Elodea Canadensis (Mouvement du protoplasme d'Élodea canadensis), 1927 - inspired Eisenstein's 'protoplasm' theory, based on the idea that primordial organisms, which have not yet achieved a stable form, are in a state that allows them to assume all possible forms through a continuous series of transformations and metamorphoses. That idea, which is most prominently the focus of Eisenstein's essay on Walt Disney, published on several occasions during the 1940s, became part of the 
reflections contained in Method, his fundamental work, which remained unpublished until 2002 and is today in the process of being translated into German, English, and Italian.

\section{Metamorphosis and protoplasm}

How does one weave together the meeting between Eisenstein and Painlevé with their convergence in the journal Documents? To respond to this question, I would like to analyse the article, edited by Georges Bataille, Michel Leiris and Marcel Griaule, entitled 'Metamorfosis', published in the 'critical dictionary' of issue 6 (1929) of Documents. ${ }^{24}$ The concept of metamorphosis serves as a lens through which one can investigate the concept of 'conflicting montage' between text and images which characterises Documents. In particular, I will analyse the images published in Documents that concern the work of Eisenstein and Painlevé.

I will then proceed to the images which illustrate the texts that anticipated the 'Metamorphosis', those containing the 'Slaughterhouse' ('Abbatoir') and 'Shellfishes' ('Crustacés') images. The entry on the 'Slaughterhouse' was illustrated with three photographs taken from a famous report on the Paris slaughterhouse by Eli Lotar. The other text, 'Shellfish', written by the surrealist poet Jacques Baron, was accompanied by two film stills ('Tête de crevette' and 'Tête de crabe') taken from Jean Painlevé's 1929 film Crabs and Shrimps (Crabes et crevettes).

In particular, I would like to dwell on the Bataille text entitled 'Metamorphosis - Wild Animals'. In it, Bataille claims: 'One can define the obsession with metamorphosis as a violent need, which can be confused with each of our animal needs, provoking man to deviate from the actions and behaviours that human nature requires. ${ }^{25}$ Here, metamorphosis coincides with the deconstruction and the mockery of anthropomorphism through its relationship with the theme of 'animality'. The Bataillean idea of metamorphosis immediately calls into question the possibility of identifying similarities between mankind and animals, through a process of elevation and verticalisation of the animal form; rather, the metamorphosis is realised by lowering the human figure to the level of 'animality', along the horizontal axis of animal forms.

These two texts can also be read through the images that precede and accompany them: 'Head of Crab' and 'Head of Shrimp' ('Tête de crevette' and 'Tête de crabe'), the frames from Crabes et crevettes shot by Painlevé in his studio in Port Blanc, Britanny (another famous work shot in Port Blanc is the photograph 'Pince de homard' ('Lobster Claw'). 
First, it is important to remember that one of the characteristics of Painlevé's films - considered radical in its contribution to the documentary genre - is the inclusion of an element of dramatisation and anthropomorphism. For example, in L'Hippocampe (The Seahorse) 1933, he describes how the female seahorse transmits the eggs to the male, which gives birth to them, creating, according to Roxanne Hamery, a 'science fiction' ('mise en fiction de la science'), a film capable of relating surrealism to science. ${ }^{26}$

Painlevé always laid claim - almost to the point of provocation - to the use of anthropomorphism in his films: 'We make the anthropomorphism, we have the right and the duty to make the anthropomorphism. ${ }^{27}$ To better communicate with the public, so that it could become aware of and distance itself from said anthropomorphism, Painlevé continued his Bataillean discourse on 'formless similarity'. In this type of similarity, the analogies between man and animal are always pointed up with irony using specific cinematographic techniques (like a close-up or blow-up) intended to ridicule or belittle the idealisation of the human form.

The montage of the Crab Head and Shrimp Head images can be read as a sort of visual prelude to the 'Metamorphosis' articles, corresponding to two possible readings. The first pertains, obviously, to the metamorphosis as a step down towards the lower and more elemental forms of animal nature (crabs and shrimp); the other might refer to the idea of metamorphosis as protoplasmaticity, or rather, as the capacity of the most basic organisms to assume any form, as per Eisenstein's subsequently formulated theory.

I would further note that, before shooting Crabes et crevettes, Painlevé had made the film titled Protoplasm Movement in Elodea Canadensis (the title refers to an aquatic plant of the Hydrocharitaceae family), a research film that Eisenstein probably knew about. The only thing that we know with certainty is that Eisenstein saw Painlevés 1928 film The Hermit Crab (Le Bernard L'Ermite) at the International Congress of Independent Cinema in 1929, and that he was profoundly moved. As Eisenstein's states in his Memoires: 'Young though he was, he made fascinating films. Documentaries. I had seen one of his films only recently at an independent film festival. It was very interesting and the camera work was first-rate. It was about the underwater life of the hermit crab. His close ups showing the life cycles of water fleas and his fantastically beautiful film about sea-horses are as involved as an intricate composition by Méliès. ${ }^{28}$

One can therefore advance the hypothesis that, on the one hand, Eisenstein's montage theory took a turn in an 'anthropological' direction 
after encountering the ethnologist collaborators from Documents, and, on the other, Painlevé's films had an influence on Eisenstein's 'protoplasmaticity' theory, which is at the centre of his reflections and writings on Disney. According to Eisenstein's explication in Method, primordial organisms that have not yet reached a stable form find themselves in an open state, capable of assuming any form by means of a series of transformations and metamorphoses, and therefore of taking on any form of animal existence. Mickey Mouse, a quintessential protoplasmic figure, was for Eisenstein an ecstatic character (always beside himself) who embodied the 'plasmaticity' of existence, a figure from whom everything could arise (indistinct society, primordial communism). In one chapter of Method entitled 'Shift from the biological', ${ }^{29}$ Eisenstein reflects on the isomorphism of natural and human history, springing from the structural identity shared by all living phenomena. This fact allows him to trace an evolutionary line, a sort of 'jumping chronology' in which qualitative leaps link the most basic and primitive forms of existence, from the fluid appearance of plasma to man. In a paragraph of his notes on Disney entitled The Animal Epic, Eisenstein states:

Man in the image - the form of the animal. [...]

The animal 'form' is a step backward in evolution with respect to 'content' - man! [...]

The very idea, if you will, of an animated cartoon (animation: literally, a drawing brought to life) is practically a direct manifestation of the method of animism. Whether the momentary endowment of life and soul of an inanimate object, which we retain from the past, for example, when we bump into a chair and swear at it as if it were a living thing, or the prolonged endowment with life that primitive man confers upon inanimate nature.

In this way, what Disney does is connected with one of the deepest features of the early human psyche. ${ }^{30}$

In this note, Eisenstein was keen on understanding 'animism' not merely as a primitive belief system in which all natural things, and all inanimate objects, have spirits and conscious life, but, as Anselm Franke observes in his introduction to the volume on Animism, 'Animism doesn't exhibit or discuss artefacts of cultural practices considered animist. Instead, it uses the term and its baggage as an optical device, a mirror in which the particular way modernity conceptualises, implements, and transgresses boundaries can come into view. ${ }^{31}$ 
In Eisenstein's view, the animated cartoon is 'the most immediate concretisation of animism'. In Disney's drawings, line delimits form; it is always in ecstasy, always in motion: animation is a 'drawing brought to life. ${ }^{32}$ In this sense, cinema is a true animist medium ${ }^{33}$ in that it allows something that is not alive (like a drawing) to be transformed, through movement and continuous metamorphosis of form, into an 'animated cartoon'. The Eisensteinian idea of animism is thus reflected in the 'proteic' and 'protoplasmatic' nature of the Disney drawing.

On this point, in another paragraph entitled Animism, Eisenstein claims:

In English, the moving drawings of Disney are called ... an animated cartoon. In this term both concepts are bound together: both 'animation' (anima - the soul) and 'liveliness' (animation - liveliness, mobility).

And surely, the drawing is 'animated through mobility'.

Even this condition of indissolubility - of unity - of animation and mobility is already deeply 'atavistic' and completely in accordance with the structure of primitive thought. ${ }^{34}$

So let us return to the link between Eisenstein and Painlevé, which Eisenstein mentions in his travel diaries, to corroborate the hypothesis regarding Painlevé's influence on Eisenstein's theories of protoplasm. Take, for example, a page from his diary dated 2 January, $1930 .^{35}$ After a reference to the stigmata in Saint Augustine, where 'the blood flows from the glove hot and cold water from the washbasin' Eisenstein refers to 'The solitary crab - Hyas', a seated crab that resembles an Indian religious deity (the 'Buddha's arms.'). $\mathrm{He}$ continues by drawing a crab that looks like a 'Buddha in prayer', which Painlevé ironically mentions in the commentary that accompanies one of his films. Finally, Eisenstein concludes his notes by stating: 'Three days ago I was at Painlevé's. He blows up the images to 200 times larger. ${ }^{36}$

The 'hyas', this type of crab that resembles Kali as much as Buddha, is most likely a reference to Painlevé's film Hyas and Stenorhynchus (Hyas et Sténorinques, 1928), which even on the basis of this note we can assume Eisenstein has seen. The documentary shows the crustaceans hyas and stenorhynchus, complete opposites in terms of form, but always together, disguised as or dressed in either sponges or seaweed, with which they are often confused. 


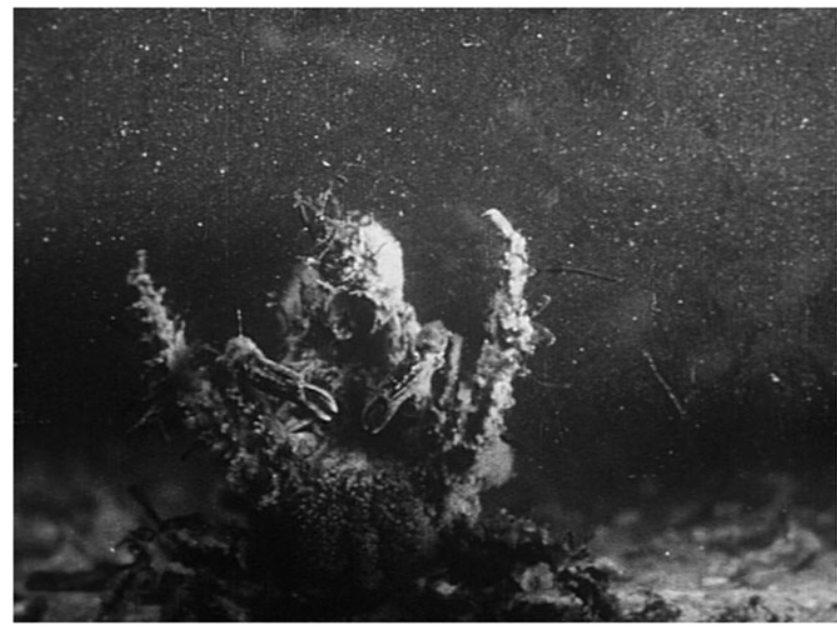

Still from Jean Painlevé, Hyas et Sténorinques, 1928, 35 mm, N/B, 9mn. (C) Archives Jean Painlevé, Paris

In conclusion, there are strong indications that Painlevé's documentary films influenced, if not directly inspired, Eisenstein's idea of protoplasmaticity, understood as a continuing metamorphosis and montage of all forms, from the most basic to the most complex, from unicellular organisms to man. As Oksana Bulgakowa points out in the afterword to Eisenstein's notes on Disney: 'He [Eisenstein] saw the grounds of Disney's effect in the (utopian) promise of freedom from ossified form, which allows for a state of eternal flux and becoming, and a freedom in the relationship between man and nature. [...] Art could thus be considered an anthropological necessity. ${ }^{, 37}$

\section{Notes}

1 The text was first presented at the NECS Conference 2015 in Eódź (Poland) on a panel with Ada Ackerman, Natalie Ryabchikova and Elena Vogman entitled 'Living Archives of Sergei Eisenstein: Correspondence, Library, Diary.'

2 See D. Ades and S. Baker, Undercover Surrealism: Georges Bataille and DOCUMENTS (Cambridge MA: MIT Press, 2006).

3 A. Breton, 'Second Manifeste du surréalisme', La Révolution surréaliste, 12 (1929). English translation, Manifestoes of surrealism, trans. Richard Seaver and Helen R. Lane (Ann Arbor: University of Michigan Press, 1969).

4 S.M. Eisenstein, 'Épopée', in Selected Works, vol. 4, Beyond the Stars: The Memoirs of Sergei Eisenstein, Selected Works, ed. R. Taylor (London: British Film Institute; Calcutta: Seagull Books, 1995), 213.

5 See G. Didi-Huberman, La Ressemblance informe, ou le gai savoir visuel selon Georges Bataille (Paris: Macula, 1995), 280-333. 
6 S.M. Eisenstein, 'Beyond the Shot' (1929), in Selected Works, vol. 1, ed. and trans. Richard Taylor (London: BFI, 1988), 138-50; 'Perspectives' (1929), ibid., 151-60; 'The Dramaturgy of Film Form' (1929), ibid., 161-80; 'The Fourth Dimension in Cinema' (1929), ibid.,181-94.

7 Document [1929-30], 2 vols, repr. D. Hollier (Paris: Éditions Jean Michel Place, 1991).

8 Ibid., 4 (1930), 218-9.

9 G.-H. Rivière, 'La Ligne générale', Documents, 4 (1930), 217. Translations from French are mine throughout.

10 S.M. Eisenstein, 'The Principles of the New Russian Cinema', in Selected Works, vol. 1, 195-202.

11 O. Bulgakowa, Sergei Eisenstein: A Biography (San Francisco: Potemkin Press, 2001), 105.

12 L. Lévy-Bruhl, La Mentalité primitive (Paris: Alcan, 1922); English edn, The Notebooks on Primitive Mentality, trans. P.G. Rivière (New York: Harper and Row, 1975); see also M. Salazkina, In Excess: Sergei Eisenstein's Mexico (Chicago: University of Chicago Press, 2009), 34-7.

13 Eisenstein, Beyond the Stars, 208-9.

14 G. Bataille. 'L’Amérique disparue', Cahiers de la République des lettres, des sciences et des arts, 11 (1928); Oeuvres complètes, vol. 1, Premiers écrits, 1922-1940 (Paris: Gallimard, 1970), 152-8. English trans. A. Michelson, October, 36 (1986), 3-9.

15 Cf. RGALI (Russian State Archive of Literature and Art), 1923-2-1116, 4 (4 January 1930). I would like to thank Elena Vogman for sharing this note with me.

16 S.M. Eisenstein, 'Epopée', 208-9.

17 S.M. Eisenstein, 'Bookshops', Beyond the Stars, 372.

18 See M. Rebecchi, '1929-1932: de Paris à Tehuantepec. Eisenstein et la vision surréaliste du Mexique', in Eisenstein: Leçons mexicaines. Cinéma, anthropologie, archéologie, ed. L. Schifano and A. Somaini (Paris: Presses universitaires de Paris Ouest, 2016), 101-15.

19 In the 1930s Eisenstein defined his interest in the pre-natal stage of life, the so-called 'immersion in the maternal womb', using the German term Mutterleibversenkung (MLB).

20 S.M. Eisenstein, 'Epopée - The Sorbonne', Beyond the Stars, 185-96.

21 Ibid., 207.

22 Letter from S.M. Eisenstein to Jean Painlevé, 1930 (Archives Jean Painlevé: 00577 1/1 Eisenstein). During his stay in France, Eisenstein went to Sainte Thérèse de Lisieux but he did not visit Lourdes (his time in France did not coincide with the dates of the pilgrimages). See Eisenstein, 'Epopée', 210.

23 Quoted in B. Berg, 'Contradictory Forces: Jean Painlevé, 1902-1989', in Science is Fiction: The Films of Jean Painlevé, ed. A.M. Bellows, M. McDougall, B. Berg (London: MIT Press, 2001), 22.

24 G. Bataille, M. Griaule, M. Leiris, 'Métamorphose', Documents, 6 (1929), 332-4.

25 G. Bataille, 'Métamorphose - Animaux sauvages', Documents, 6 (1929), 333-4.

26 R. Hamery, Jean Painlevé: Le Cinéma au cour de la vie (Rennes: Presses universitaires de Rennes, 2009), 57-70.

27 Ibid., 83. See Denis Derrien, Hélène Hazéra, Jean Painlevé au fil de ses films ('Les Documents cinématographiques'/GMT/La Sept, 1988). See 
also R. Hamery, 'Jean Painlevé et la promotion du cinéma scientifique en France dans les années trente', 1895, AFRHC (Association française de recherche sur l'histoire du cinéma), 47 (2005), 78-95.

28 Eisenstein, Beyond the Stars, 203-4.

29 S.M. Eisenstein, Metod, vol. I, ed. N. Kleiman (Moscow: Muzei Kino, 2002), 278-95. See A. Cervini. La Ricerca del metodo. Antropologia e storia delle forme in S.M. Ejzenstejn (Milan: Mimesis, 2010), 60.

30 S.M. Eisenstein, Disney, ed. Oksana Bulgakowa and Dietmar Hochmuth, trans. Dustin Condren (Berlin: Potemkin Press, 2011), 33.

31 A. Franke, 'Much Trouble in the Transportation of Souls, or The Sudden Disorganization of Boundaries', Animism, vol. 1, ed. A. Franke (Berlin: Sternberg Press; Antwerp: Extra City and M HKA, 2010), 11.

32 S.M. Eisenstein, Disney, 33.

33 Cf. T. Castro, 'Penser le "cinéma animiste" avec Jean Epstein', Jean Epstein. Actualités et postérités, ed. Roxanne Hamery and Éric Thouvenel (Rennes: Presses universitaires de Rennes, 2016), 247-60.

34 Eisenstein, Disney, 51; ellipsis in original.

35 RGALI, 1923-2-1116, 1 (2 January 1930).

36 Ibid. I would like to thank Elena Vogman for the translation and discussion of this page of Eisenstein's diary.

37 O. Bulgakowa, 'Self Portrait as Someone Else', in Eisenstein, Disney, $140-41$. 